\title{
Effect Of Changes In The Korean Accounting Environment On The Productivity Of Accounting Firms
}

Sun Min Kang, Chung-Ang University, South Korea

In Tae Hwang, Chung-Ang University, South Korea

Kang Sung Hur, Chung-Ang University, South Korea

\begin{abstract}
To investigate how changes in the accounting environment in Korea affect firm productivity, this study analyzes productivity by firm size and labor type from 2000 to 2014, using a Cobb-Douglas production function. We find that (1) the greater the management advisory (tax) revenue, the greater the total revenue in large (small) accounting firms; and (2) marginal revenue is greatest for partners, followed by certified public accountants and general employees. In particular, partners' contribution to large accounting firms improved after 2007, whereas general employees made a significant positive contribution to total revenue before 2007.
\end{abstract}

Keywords: Accounting Environment; Accounting Firms; Production Function; Marginal Revenue

\section{INTRODUCTION}

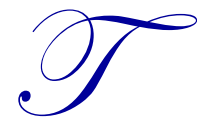

he international accounting and audit market has undergone important changes since 2000. The United States enacted the Sarbanes-Oxley (SOX) Act in 2002 to enhance the transparency and reliability of accounting information; the EU also adopted reformative accounting acts in 2014. In addition, the EU and Australia introduced the International Financial Reporting Standards (IFRS) in 2005. At the same time, the radical development of information technology (IT) has continually increased firms' demand for management advisory services, and the rise in international trade and financial transactions has increased the demand for tax consulting services (i.e., services that support the settlement of international tax disputes and adjustments) as well as traditional tax adjustment services. These environmental changes have greatly expanded the market for non-audit services for accounting firms.

Meanwhile, Korea also improved corporate governance and restricted non-audit services to strengthen the independence of auditors by revising its external corporate audit and certified public accountant (CPA) laws in 2003. In preparation for the increase in demand for accounting services, Korea reformed the CPA examination system, which radically increased the number of new CPAs from 300 to 1,000 per year. In addition, Korea announced an IFRS roadmap in 2007 and has applied IFRS to all listed companies since 2011. As a result, the number of firms subject to external audit has increased fourfold since 2000, with the total revenue of accounting firms rising from 538 billion won in 2000 to 2.226 trillion won in 2014. Moreover, the ratio of total revenue derived from tax and management advisory services increased from $58 \%$ to $65 \%$.

The total revenue and human resources of large accounting firms ${ }^{1}$ relative to those of all accounting firms has changed enormously over the past 15 years. The total revenue share of large accounting firms in the accounting market decreased from $76 \%$ in 2000 to $60 \%$ in 2014, and the proportion of CPAs in large accounting firms decreased from

\footnotetext{
${ }^{1}$ In this study, large accounting firms are defined as those with over 100 employees for the past 10 consecutive years among domestic accounting firms that have affiliations with the 10 largest accounting firms globally, based on sales revenues, namely, Samil (PwC), Anjin (Deloitte), Samjung (KPMG), Hanyoung (E\&Y), Daejoo (BDO), Samduk (Nexia), and Shinhan (RSM).
} 
$79 \%$ to $65 \% .^{2}$ On the contrary, the market share and proportion of CPAs in small accounting firms increased. However, in the auditing market for listed companies, the market share of the Big 4 increased from $50 \%$ before the introduction of IFRS to $75 \%$ thereafter (Money Today, 2012).

This study analyzes the extent to which these changes in the accounting environment have influenced the revenue and human resources of large and small accounting firms. Specifically, it classifies revenue into audit, tax, and management advisory revenue and human resources into partners, CPAs, and general employees, according to the Regulation on Human Resources Structure of Accounting Firms ${ }^{3}$ in the CPA law. This study then analyzes whether changes in the accounting environment affect the productivity of human resources depending on the firm size. To this end, this study analyzes the relationship between the human resources input and revenue of accounting firms, using data taken from the business reports of accounting firms for 2000 to 2014 and a Cobb-Douglas production function (Cobb \& Douglas, 1928). Additionally, this study examines how each category of human resources contributes to the total revenue of accounting firms, as well as whether affiliation with an overseas accounting firm affects the relationship between human resources input and total revenue, based on labor classification.

The remainder of this paper is organized as follows. Section 2 reviews previous studies and explains the background of this study. Section 3 establishes the hypotheses to be verified. Section 4 presents the study design, while Section 5 explains the results of the empirical analysis. Finally, Section 6 summarizes the results and suggests directions for future research.

\section{LITERATURE REVIEW}

\section{Accounting Regulatory Changes and Korean Accounting Market}

In response to changes in the international accounting environment, Korea has revised its related laws as well as introduced and applied new systems, markedly affecting the demand for and supply of the services provided by accounting firms (Barros, Couto, \& Samagaio, 2014). Thus, to analyze the productivity of domestic accounting firms, one needs to understand the factors affecting the competition among them. Changes in the number of firms subject to the Act on External Audit of Stock Companies (AEASC) and their assets are important factors of the accounting environment affecting the revenue of accounting firms. Figure 1 shows the total assets, sales, and number of firms subject to mandatory external audits from 2000 to 2014, according to the AEASC. As shown in Figure 1, the number of firms subject to the AEASC increased fourfold from 5,168 in 2000 to 20,861 in 2014, while total assets and sales increased by similar amounts over the same period.

\footnotetext{
${ }^{2}$ The Big 4 are defined as Samil (PwC), Anjin (Deloitte), Samjung (KPMG), and Hanyoung (E\&Y). The revenue of the Big 4, as a ratio of the total revenue of all accounting firms, decreased from $69 \%$ in 2000 to $54 \%$ in 2014 , and their relative share in terms of the number of CPAs decreased from $70 \%$ in 2000 to $56 \%$ in 2014 .

${ }^{3}$ An accounting firm is composed of three executives who are CPAs and must be partners in the accounting firm. In addition, the firm must have more than $10 \mathrm{CPAs}$, including executives and employees.
} 
Figure 1. Trends of Firms Subject to External Audit.

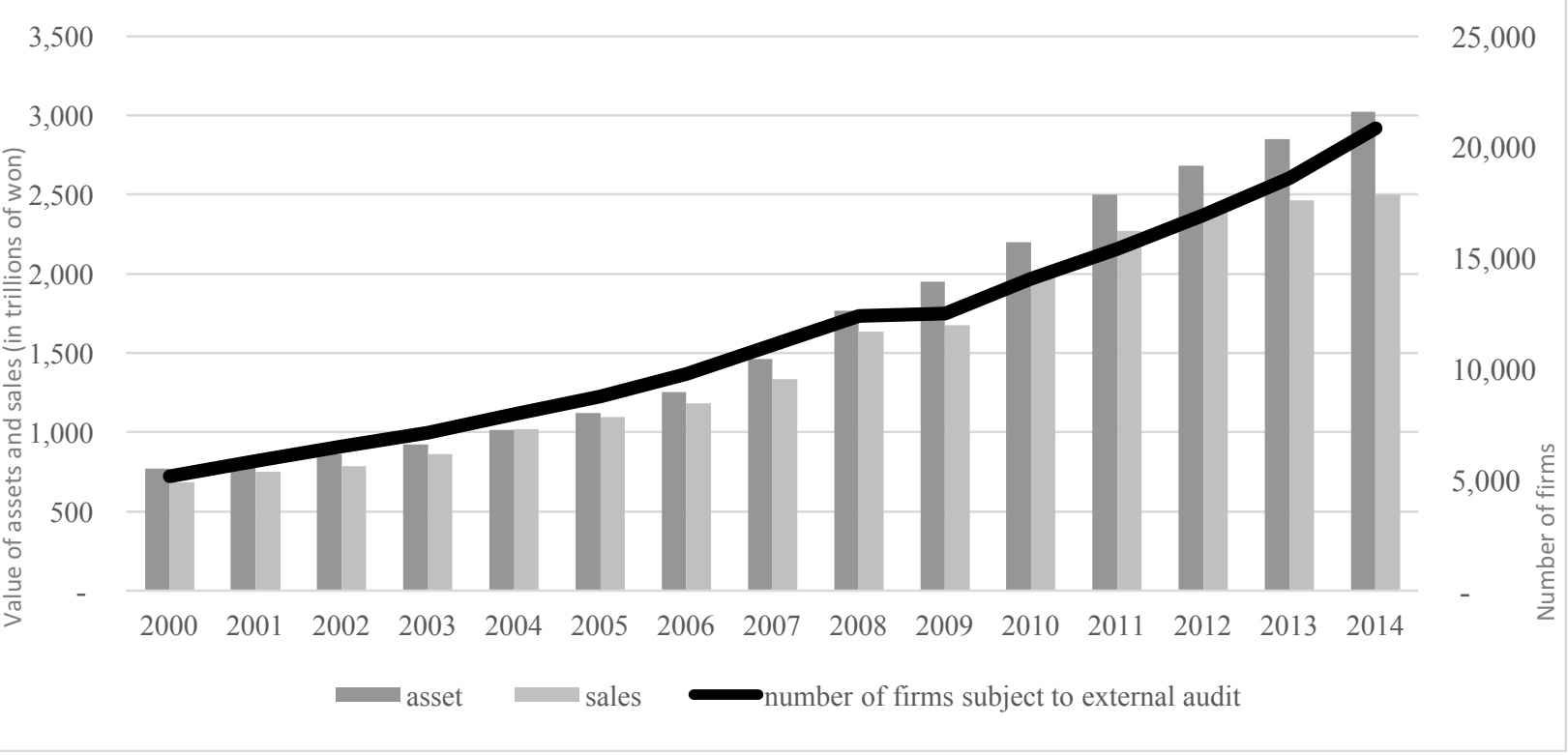

Table 1 and Figures 2, 3 show the 15-year trend of revenue and human resources in accounting firms. The total revenue of accounting firms has increased more than fourfold and the number of CPAs has increased more than threefold since 2000. Further, Panel A of Table 1 shows that the total revenue of small accounting firms has increased almost sevenfold during this period, more than threefold the rise in large accounting firms. Likewise, the number of CPAs in small accounting firms increased by a rate twice as high as that in large accounting firms (see Panel B of Table 1). Revenue per CPA also differs between large and small accounting firms, increasing from 150 to 200 million won in large and from 180 to 250 million won in small accounting firms over the period 2000 to 2014.

Figure 2. Trends of Revenue of Accounting Firms.

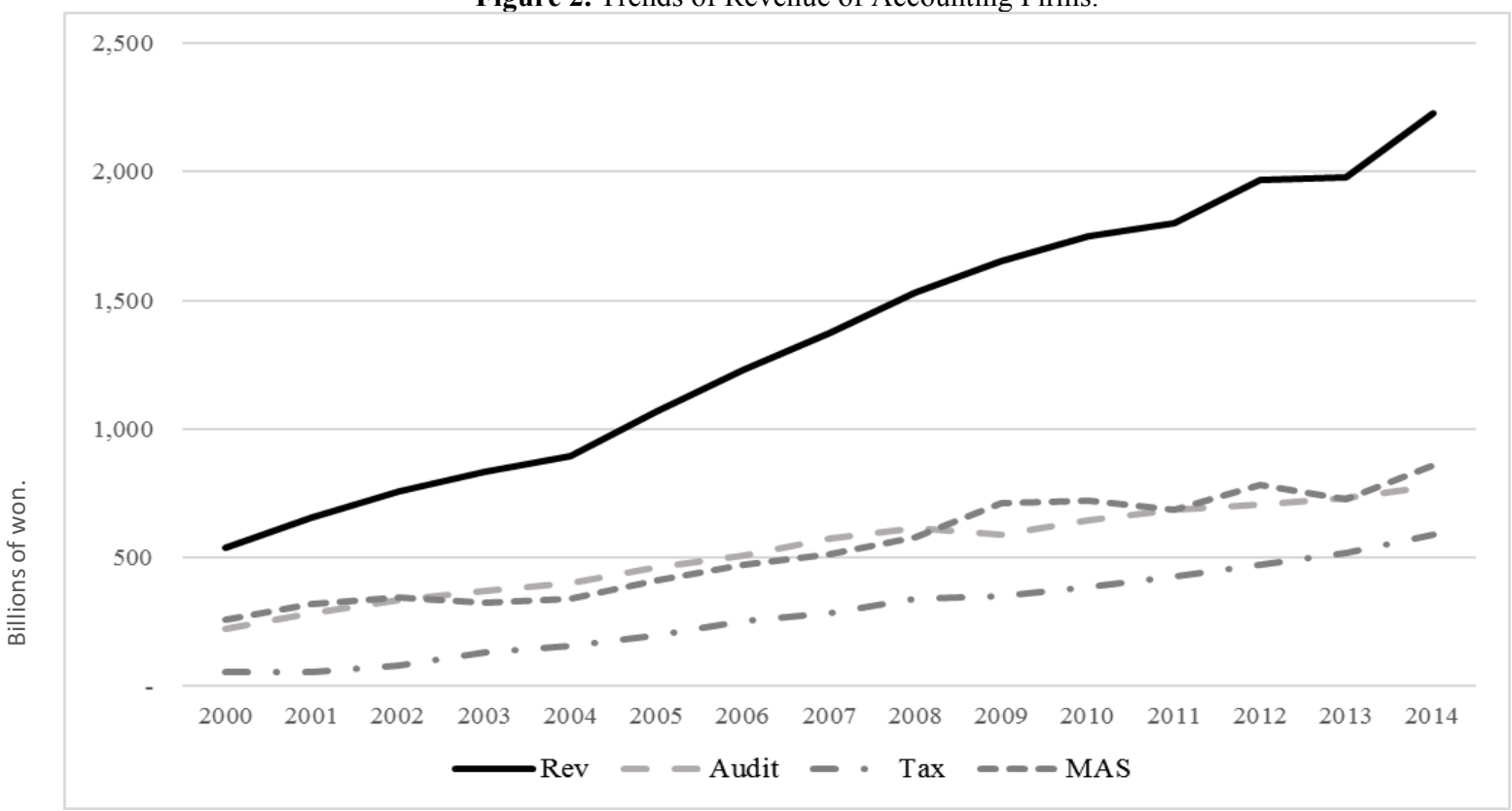

Notes: Rev: Total revenue; Audit: Audit revenue; Tax: Tax revenue; MAS: Management advisory services revenue. 
Figure 3. Trends of Human Resources of Accounting Firms.

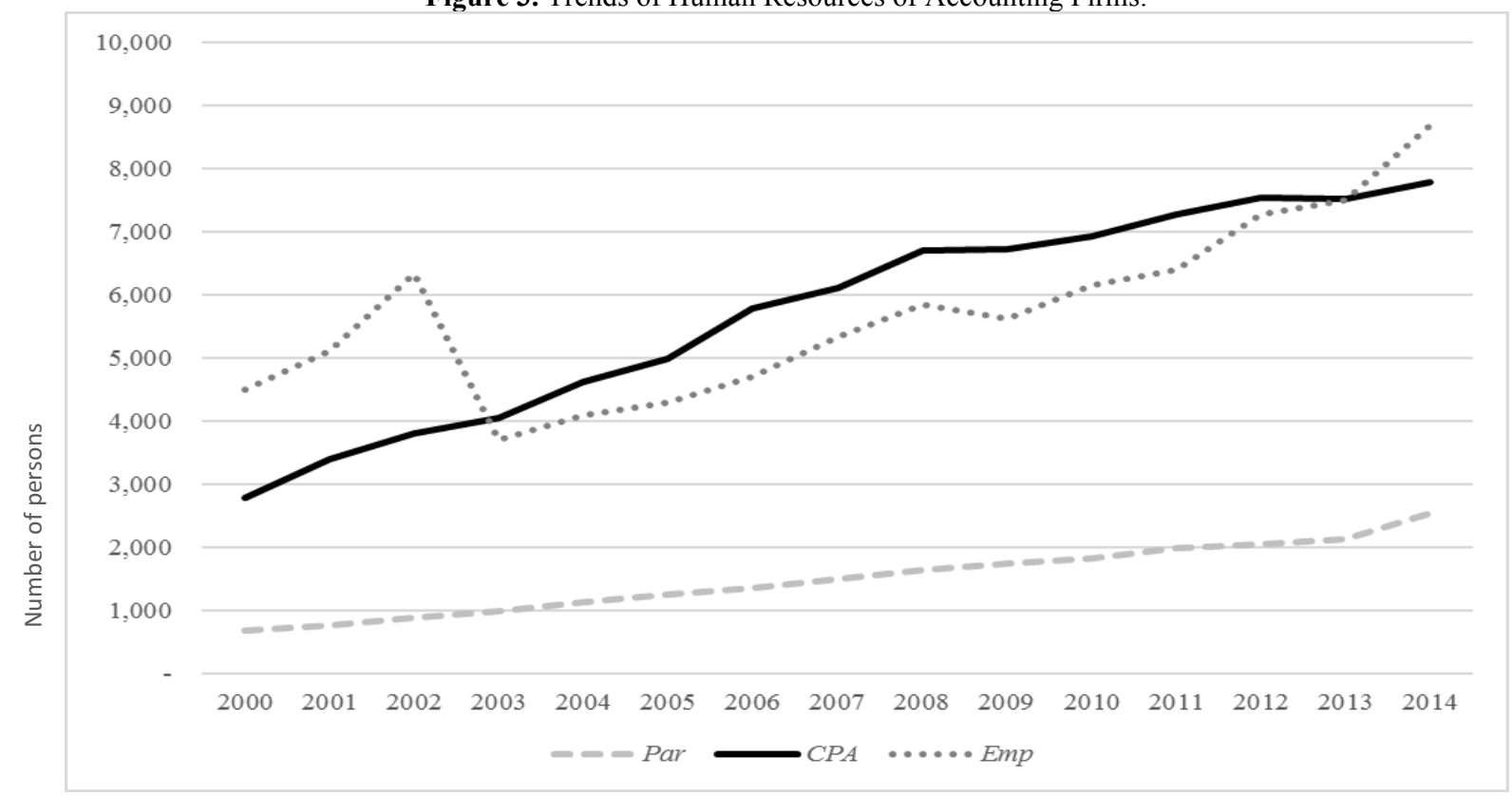

Notes: Par: Number of partners; CPA: Number of CPAs; Emp: Number of other employees.

Table 1. Revenue and human resources trends of accounting firms

\begin{tabular}{|c|c|c|c|c|c|c|c|c|}
\hline \multirow{2}{*}{\multicolumn{9}{|c|}{$\begin{array}{l}\text { Panel A: Service revenue by year } \\
\text { (Unit: billion won) }\end{array}$}} \\
\hline & & & & & & & & \\
\hline & 2000 & 2001 & 2002 & 2003 & 2004 & 2005 & 2006 & 2007 \\
\hline \multicolumn{9}{|c|}{ Full sample } \\
\hline $\operatorname{Rev}$ & 538 & 658 & 759 & 831 & 897 & 1,069 & 1,232 & 1,373 \\
\hline Audit & 225 & 284 & 334 & 373 & 403 & 460 & 507 & 575 \\
\hline $\operatorname{Tax}$ & 55 & 55 & 79 & 131 & 155 & 198 & 253 & 285 \\
\hline$M A S$ & 258 & 319 & 345 & 328 & 338 & 410 & 472 & 513 \\
\hline \multicolumn{9}{|l|}{ Large } \\
\hline Rev & 407 & 506 & 547 & 571 & 633 & 746 & 819 & 887 \\
\hline Audit & 179 & 227 & 257 & 274 & 306 & 342 & 366 & 409 \\
\hline $\operatorname{Tax}$ & 33 & 28 & 35 & 43 & 82 & 112 & 141 & 156 \\
\hline$M A S$ & 195 & 250 & 254 & 254 & 245 & 293 & 312 & 322 \\
\hline \multicolumn{9}{|l|}{ Small } \\
\hline Rev & 131 & 152 & 212 & 261 & 264 & 323 & 414 & 485 \\
\hline Audit & 47 & 58 & 77 & 99 & 97 & 118 & 141 & 166 \\
\hline $\operatorname{Tax}$ & 22 & 26 & 44 & 88 & 73 & 86 & 112 & 128 \\
\hline$M A S$ & 63 & 69 & 92 & 74 & 93 & 118 & 160 & 191 \\
\hline
\end{tabular}

(Table 1 continued on next page) 
(Table 1, Panel A continued)

\begin{tabular}{|c|c|c|c|c|c|c|c|}
\hline \multicolumn{8}{|c|}{$\begin{array}{l}\text { Panel A: Service revenue by year } \\
\text { (Unit: billion won) }\end{array}$} \\
\hline & 2008 & 2009 & 2010 & 2011 & 2012 & 2013 & 2014 \\
\hline \multicolumn{8}{|c|}{ Full sample } \\
\hline Rev & 1,533 & 1,651 & 1,751 & 1,802 & 1,966 & 1,977 & 2,226 \\
\hline Audit & 616 & 589 & 643 & 686 & 709 & 731 & 780 \\
\hline Tax & 339 & 353 & 387 & 428 & 474 & 518 & 588 \\
\hline$M A S$ & 578 & 710 & 721 & 688 & 784 & 728 & 859 \\
\hline \multicolumn{8}{|l|}{ Large } \\
\hline Rev & 989 & 1,110 & 1,184 & 1,184 & 1,293 & 1,260 & 1,334 \\
\hline Audit & 421 & 406 & 451 & 482 & 496 & 511 & 520 \\
\hline $\operatorname{Tax}$ & 180 & 189 & 213 & 225 & 243 & 282 & 296 \\
\hline$M A S$ & 388 & 515 & 519 & 477 & 554 & 466 & 517 \\
\hline \multicolumn{8}{|l|}{ Small } \\
\hline$R e v$ & 544 & 541 & 567 & 618 & 674 & 717 & 893 \\
\hline Audit & 195 & 182 & 192 & 204 & 213 & 220 & 259 \\
\hline $\operatorname{Tax}$ & 159 & 164 & 174 & 203 & 230 & 236 & 292 \\
\hline$M A S$ & 190 & 195 & 201 & 211 & 230 & 262 & 342 \\
\hline
\end{tabular}

Panel B: Human resources by year

(Unit: number of persons)

\begin{tabular}{|c|c|c|c|c|c|c|c|c|}
\hline & 2000 & 2001 & 2002 & 2003 & 2004 & 2005 & 2006 & 2007 \\
\hline \multicolumn{9}{|c|}{ Full sample } \\
\hline Par & 683 & 767 & 891 & 993 & 1,131 & 1,253 & 1,364 & 1,508 \\
\hline$C P A$ & 2,792 & 3,391 & 3,806 & 4,061 & 4,625 & 5,001 & 5,784 & 6,112 \\
\hline Emp & 4,505 & 5,107 & 6,330 & 3,709 & 4,085 & 4,307 & 4,707 & 5,338 \\
\hline \multicolumn{9}{|l|}{ Large } \\
\hline Par & 290 & 311 & 351 & 379 & 384 & 458 & 482 & 509 \\
\hline$C P A$ & 2,444 & 2,842 & 2,985 & 3,086 & 3,790 & 4,037 & 4,482 & 4,956 \\
\hline Emp & 2,797 & 3,173 & 3,823 & 1,871 & 2,111 & 2,145 & 2,132 & 2,341 \\
\hline \multicolumn{9}{|l|}{ Small } \\
\hline Par & 393 & 456 & 540 & 614 & 747 & 795 & 882 & 999 \\
\hline$C P A$ & 348 & 549 & 821 & 975 & 835 & 964 & 1,302 & 1,156 \\
\hline$E m p$ & 1,708 & 1,934 & 2,507 & 1,838 & 1,974 & 2,162 & 2,575 & 2,997 \\
\hline
\end{tabular}

(Panel B continued)

\begin{tabular}{|c|c|c|c|c|c|c|c|}
\hline \multicolumn{8}{|c|}{$\begin{array}{l}\text { Panel B: Human resources by year } \\
\text { (Unit: number of persons) }\end{array}$} \\
\hline & 2008 & 2009 & 2010 & 2011 & 2012 & 2013 & 2014 \\
\hline \multicolumn{8}{|c|}{ Full sample } \\
\hline Par & 1,653 & 1,743 & 1,828 & 1,989 & 2,052 & 2,132 & 2,541 \\
\hline$C P A$ & 6,715 & 6,725 & 6,927 & 7,278 & 7,546 & 7,516 & 7,776 \\
\hline$E m p$ & 5,846 & 5,626 & 6,155 & 6,405 & 7,284 & 7,490 & 8,688 \\
\hline \multicolumn{8}{|l|}{ Large } \\
\hline Par & 506 & 650 & 665 & 693 & 712 & 729 & 737 \\
\hline$C P A$ & 5,379 & 5,390 & 5,538 & 5,872 & 6,091 & 5,994 & 5,941 \\
\hline Emp & 2,272 & 2,257 & 2,523 & 2,491 & 3,186 & 3,237 & 3,284 \\
\hline \multicolumn{8}{|l|}{ Small } \\
\hline Par & 1,147 & 1,093 & 1,163 & 1,296 & 1,340 & 1,403 & 1,804 \\
\hline$C P A$ & 1,336 & 1,335 & 1,389 & 1,406 & 1,455 & 1,522 & 1,835 \\
\hline$E m p$ & 3,5 & & & & 4,0 & 4,253 & 5,404 \\
\hline
\end{tabular}

Notes: Rev: Total revenue; Audit: Audit revenue; Tax: Tax revenue; MAS: Management advisory services revenue; Par: Number of partners; CPA: Number of CPAs; Emp: Number of other employees; Large: Dummy variable that equals one if the firm is large, and 0 otherwise; Year: Dummy variable that equals one if year $\mathrm{t}=2000-2014$, and 0 otherwise. 
Although the ratio of general employees to CPAs differed between small and large accounting firms, this gap has decreased over time. Specifically, the ratio of general employees to CPAs was 1.02 in 2000 and 0.49 in 2014 for large firms, compared to 2.3 and 1.5 , respectively, for small firms. This is presumably because small accounting firms need more input from general employees than do professionals, since they typically focus on tax services such as bookkeeping as well as drawing up and reporting tax forms, rather than audit services. The decrease in the proportion of general employees over time, irrespective of firm size, is attributable to the radical increase in the number of CPAs who passed the CPA exam due to the revision of the CPA law. In Figure 3, the decrease in the number of general employees in 2003 is presumably due to the separation of labor for management advisory services because of the prohibition on the simultaneous provision of non-audit and audit services under the revised CPA law. The number of partners relative to CPAs also differed between small and large firms, with 2 partners in 2000 and 1.4 in 2014 per 10 CFAs in large accounting firms compared with 13 and 11 partners, respectively, in small accounting firms. Thus, the number of partners is greater than the number of CPAs in small accounting firms.

\section{Previous Studies}

Numerous studies have analyzed whether changes in accounting systems, regulations, and environments increase or decrease the productivity or efficiency of accounting firms (Banker, Chang, \& Cunningham, 2003; Banker, Chang, \& Natarajan, 2005; Banker, Chang, \& Natarajan, 2007; Chang, Choy, Cooper, \& Parker, 2009a; Chang, Choy, Cooper, \& Parker, 2009b; Chang, Huang, \& Kuo, 2015; Hwang, Kang, \& Hur, 2015; Hwang, Kim, \& Jeon, 2005; Lee \& Kim, 2001). Lee and Kim (2001) analyzed the relationship between the human resources input and revenue of Korean accounting firms from 1997 to 1999 by using a Cobb-Douglas production function. They observed the effect of scale economies in small accounting firms and found that management advisory services have a greater revenue-generating effect than do auditing services. Additionally, they observed that accounting firms affiliated with the Big 4 generated higher revenue than did domestic accounting firms without such an affiliation. Until then, the previous studies of auditing had mainly analyzed the auditing remuneration model, input decisions of the auditing time model, the industrial specialization of the auditing market, and the effect of the Big 4's reputation. By contrast, Lee and Kim (2001) attempted to analyze total revenue and labor productivity by using a production function. However, their study only classified labor into CPAs and employees. Moreover, the study by Lee and Kim (2001) was based on data collected from 1997 to 1999, the period in which the Asian financial crisis occurred and numerous reform measures were taken. Indeed, during this period, the non-audit revenue of accounting firms rapidly increased as consulting demand rose (e.g., due diligence for restructuring companies and financial institutions). Hence, it is difficult to generalize their analytical results to periods after 2000. This limitation was also suggested by Hwang et al. (2005).

By applying a translog production function, Banker et al. (2003) analyzed the relationship between the revenue and human resources of accounting firms. By drawing on annual data on the largest 64 accounting firms during 1995 to 1999, they verified the increasing trend in productivity for accounting firms and, based on this result, justified mergers and acquisitions (M\&As) as a means of expanding their scale. In addition, according to Banker et al. (2005), the productivity of 64 large accounting firms in the United States increased by $9.5 \%$ on average during 1995 to 1999 . The consulting service technology outside of audit and tax services contributed to a $12 \%$ increase in the overall productivity of the accounting industry; however, some of this increase was offset by the shift in technological efficiency. Thus, it can be interpreted that environmental changes, including improvements in service technology, do not necessarily affect the productivity of accounting firms in the same direction.

Banker et al. (2007) analyzed revenue and technological efficiency by using data envelopment analysis. In their analysis of the top 100 accounting firms in the United States from 1995 to 1998, they found serious inefficiency in the distribution of resources. Moreover, they argued that the human resources necessary for changing accounting technologies were insufficiently reorganized and that the redistribution of human resources could considerably reduce costs. However, as Banker et al. $(2003)$ and Banker et al. $(2005,2007)$ studied large accounting firms, it is difficult to generalize their results to all firm sizes. Further, Lee and Kim (2001) and Hwang et al. (2005) did not observe economies of scale for large accounting firms in Korea.

Moreover, Hwang et al. (2005) extended Lee and Kim (2001) by further segmenting labor classification (i.e., executives, partners, CPAs, probationary CPAs, and other employees) to investigate the contribution of each by classifying service types and accounting firms. Although the study observed partial economies of scale, it explained 
that a larger firm size does not necessarily enhance economies of scale. Further, while this study's labor classification distinguished partners, who are constituting members of accounting firms according to commercial law, into executives and non-executive partners, this is somewhat unrealistic in the accounting industry because most accounting firms are limited liability companies, meaning that when a CPA is promoted to partner, he/she is granted the position of an executive.

By using data envelopment analysis and the Malmquist Index, Chang et al. (2009b) compared the efficiency and productivity of 56 United States accounting firms before the introduction of SOX with those thereafter, and found that these firms enhanced their productivity after the introduction due to technological advances, but not to efficiency. In addition, Chang et al. (2009a) found, by using data on 62 United States accounting firms, that the increase in productivity in the accounting industry was due to the increase in revenue from management advisory services. Later, Chang et al. (2015) analyzed the productivity and technological efficiency of the United States, Chinese, and Taiwanese accounting firms for 2007 to 2009 by using a stochastic metafrontier production function. They found that Chinese accounting firms show low performance because of an uncompetitive market and government regulations, and that the metafrontier technical efficiency and technical gap ratio were high for the United States and Taiwanese firms. However, the study claimed, pointing out the decrease in economies of scale in all three countries, that increasing the production scale by M\&As might not improve productivity. Barros et al. (2014) also found, analyzing changes in productivity in UK accounting firms before and after the changes in the UK audit system in 2008, that changes in productivity were mixed before and after the regulation, regardless of the change.

\section{HYPOTHESES DEVELOPMENT}

The importance of non-audit services, such as tax and management advisory services, for creating continuous revenue streams is gradually rising for accounting firms. Revenue from non-audit services relative to total revenue increased from $58 \%$ to $65 \%$ from 2000 to 2015 . On the contrary, the ratio of traditional auditing services is in continuous decline. To ensure consistent growth, accounting firms must secure labor and knowledge assets capable of providing professional management and tax advisory services and that are superior to those of their competitors. Thus, accounting firms with a higher ratio of revenue from non-audit services are considered capable of providing differentiated management and tax advisory services. Hence, we formulate the first of our two hypotheses as follows.

Hypothesis 1: The higher the ratio of revenue from non-audit services to total revenue, the greater the revenue of an accounting firm.

In addition, O'Keefe, Simunic, and Stein (1994) and Choi (1999) analyzed how the audit time spent by each worker depends on the characteristics of the companies being audited. The audit time was found to depend on the characteristics of the companies being audited, such as the initial audit, learning effect from repeating the audit, and ratio of overseas sales. Thus, this current study aims to present the grounds for differentiating remuneration based on the ability to create revenue through the marginal revenue product (MRP) of partners, CPAs, and general employees. According to microeconomic theory, to maximize production in a given production function, the MRP ratio must be balanced with the relative price ratio of the input elements. That is, the remuneration ratio among partners, CPAs, and general employees must be the same as the MRP ratio of each group. To justify their relatively high remuneration, therefore, partners must be able to create more revenue. Hence, we propose the following hypothesis.

Hypothesis 2: A partner has higher marginal revenue than a CPA, and the latter has higher marginal revenue than a general employee.

\section{METHODS}

This study analyzes the relationship between the human resources input and revenue - as the output of accounting firms - by using a Cobb-Douglas production function. The general Cobb-Douglas production function assumed by the industry is expressed as Equation (1):

$$
Q=a \cdot K^{\alpha} \cdot L^{\beta},
$$


where $Q$ represents output; $K$ represents capital input; $L$ is labor input; and a, $\alpha$, and $\beta$ are positive constants. This equation is the production function for the capital and labor inputs. The management of a firm must then decide on the input ratio of labor and capital to maximize the production per input unit (Chiang, 1984).

Based on Equation (1), this study draws out the production function for accounting firms and analyzes the effect of human resources on their revenue. The production function of accounting firms considers labor as the only input factor because this is necessary to create revenue from accounting services. Indeed, in a professional knowledge-based industry, such as accounting, the labor cost mostly comprises payroll and welfare expenditures. By contrast, accounting firms possess little capital (e.g., buildings or machinery), and the study omits the material resources necessary for accounting services, such as office rent and furniture, as supplementary factors. Hence, the relationship between human resources and revenue can be drawn as the production function below ${ }^{4}$ :

$$
Y=e^{\beta 0} \operatorname{Par}^{\beta 1} C P A^{\beta 2} \operatorname{Emp}^{\beta 3},
$$

where $Y$ is the total revenue of an accounting firm; Par is the number of partners; $C P A$ is the number of CPAs who are not partners; Emp is the number of general employees; $e$ is the base of the natural logarithm; and $\beta_{0}, \beta_{1}, \beta_{2}$, and $\beta_{3}$ are constants.

Taking the natural logarithm on both sides of Equation (2) results in the following function form:

$$
\ln Y=\beta_{0}+\beta_{1} \ln P a r+\beta_{2} \ln C P A+\beta_{3} \ln E m p .
$$

However, as total revenue cannot be explained by human resources alone, it is necessary to add the ratio of management and tax advisory services relative to the total revenue (Banker et al., 2005; Lee, 2015; Lee \& Kim, 2001). Non-audit services such as management and tax advisory services require differentiated and professional human resources and knowledge assets, unlike audit services. Hence, the ratio of management and tax advisory services can affect the productivity of human resources and, thus, total revenue. ${ }^{5}$ The present study assumes that accounting firms with a high ratio of management and tax advisory services possess professional and differentiated human resources and knowledge assets.

In addition, since affiliation with large overseas accounting firms can affect productivity, the study added a dummy variable (Large), which represents such an affiliation, into Equation (3) (Chang et al., 2015; Hwang et al., 2005; Lee \& Kim, 2001). Further, as the accounting industry in Korea has experienced radical changes each year, this study added a dummy variable for each year to control for the yearly characteristics. The regression equation used in this study for the empirical analysis is as follows:

$$
\ln Y=\beta_{0}+\beta_{I} \ln P a r+\beta_{2} \ln C P A+\beta_{3} \ln E m p+\beta_{4} M A S \%+\beta_{5} \text { Tax } \%+\beta_{6} \text { Large }+\beta_{7} \text { Year },
$$

where $M A S \%$ is the ratio of management advisory services to total revenue; $\operatorname{Tax} \%$ is the ratio of tax services to total revenue; and Large is 1 for affiliation with a large overseas accounting firm, and 0 otherwise. The estimated $\beta_{1}, \beta_{2}$, and $\beta_{3}$ represent the percentage change in the total revenue of an accounting firm when the numbers of partners, CPAs, and general employees, respectively, change by $1 \%$; thus, they measure the effect of that labor classification on the revenue of an accounting firm. Further, Hypothesis 2 is tested by estimating the MRP below. For example, the regression coefficient $\left(\beta_{1,2,3}\right)$ of the human resources variable, which is an independent variable of Hypothesis 2 , can be converted by adopting the chain rule as follows:

$$
\frac{\partial \operatorname{lnREVENUE}}{\partial \ln H \mathrm{R}}=\frac{\partial \operatorname{lnREVENUE}}{\partial \mathrm{REVENUE}} * \frac{\partial \mathrm{REVENUE}}{\partial \mathrm{HR}} * \frac{\partial \mathrm{HR}}{\partial \ln \mathrm{HR}}=\frac{1}{\mathrm{REVENUE}} * \frac{\partial \mathrm{REVENUE}}{\partial \mathrm{HR}} * \mathrm{HR} .
$$

\footnotetext{
${ }^{4}$ In this study, the number of CPAs includes probationary CPAs based on the annual reports of accounting firms.

${ }^{5}$ As $A$ udit $\%$ (ratio of audit revenue) $+M A S \%$ (ratio of management advisory services to total revenue) + Tax\% (ratio of tax services to total revenue) $=1$, the present study does not include Audit $\%$ in the model, to avoid the problem of linear dependence among the variables occurring in the regression analysis model.
} 
From Equation (5), the relationship between the human resources input and regression coefficient $\left(\beta_{1}, \beta_{2}, \beta_{3}\right)$ of the human resources variable is induced by arranging both sides as follows:

$$
\begin{aligned}
& \frac{\partial \mathrm{REVENUE}}{\partial \mathrm{HR}}=\frac{\partial \operatorname{lnREVENUE}}{\partial \ln \mathrm{HR}} * \frac{\text { REVENUE }}{\mathrm{HR}}, \frac{\partial \mathrm{REVENUE}}{\partial \mathrm{HR}}=\frac{\partial \operatorname{lnREVENUE}}{\partial \ln \mathrm{HR}} * \frac{\text { REVENUE }}{\mathrm{HR}} \frac{\partial \mathrm{REVENUE}}{\partial \mathrm{HR}}=\frac{\partial \operatorname{lnREVENUE}}{\partial \ln H \mathrm{R}} * \frac{\text { REVENUE }}{\mathrm{HR}} \frac{\partial \text { REVENUE }}{\partial \mathrm{HR}}= \\
& \frac{\partial \operatorname{lnREVENUE}}{\partial \ln H \mathrm{R}} * \frac{\text { REVENUE }}{\mathrm{HR}} \\
& M R P(P a r, C P A, E m p)=\beta_{1,2,3} * \frac{\text { REVENUE }}{\mathrm{HR}} \text {. }
\end{aligned}
$$

The point estimation value of the MRP for each labor classification of Equation (7) can be interpreted as the marginal production elasticity, which, therefore, can be acquired by multiplying the point estimation value of the regression coefficient in each labor classification of Equation (4) by the value earned from total revenue, divided by the number of each labor classification. By using this method, the MRP can be acquired for partners, CPAs, and general employees.

\section{RESULTS}

\section{Sample Selection}

Data on revenue and human resources were acquired from the relevant business reports. ${ }^{6}$ Newly established accounting firms were excluded from the sample since they had less than one year of total revenue. Through this sample selection process, the final number of samples used in this study was 1,262 accounting firm years. Large accounting firms were those that had affiliations with the top 10 accounting firms worldwide, in terms of sales, and over 100 CPAs in Korea for the past 10 consecutive years; these included Samil (PwC), Anjin (Deloitte), Samjung (KPMG), Hanyoung (E\&Y), Daejoo (BDO), Shinhan (Nexia), and Samduk (RSM). The accounting firm years for the large and small accounting firm samples were 111 and 1,151, respectively.

\section{Descriptive Statistics}

Table 2 presents the descriptive statistics for the variables used in this study. Panel A of Table 2 shows the descriptive statistics for the revenue and human resources of the 1,262 observations from 2000 to 2014 . The mean and median revenues of accounting firms for this 15 -year period were 16.05 billion won and 5.41 billion won, respectively. The mean number of partners was 18 , and the median was 11 . Moreover, the mean number of CPAs was 68 , and the median was 11; in this case, the median was smaller than the mean since the number of CPAs is much larger in large firms than in small firms. Further, the differences in firm size can be found in Panels B and C of Table 2, which present the statistics for large and small accounting firms, respectively.

\footnotetext{
${ }^{6}$ The data were collected from the business reports submitted by the accounting firms to the Securities and Futures Commission within three months of the end of each business year, in accordance with the Act on the External Audit of Stock Companies.
} 
Table 2. Service revenue and human resources variables

\begin{tabular}{|c|c|c|c|c|c|}
\hline \multicolumn{6}{|c|}{$\begin{array}{l}\text { Panel A: Full sample }(\mathrm{n}=1,262) \\
\text { (Unit: millions of won, number of persons) }\end{array}$} \\
\hline Variables & Mean & Std & $25 \%$ & Med & $75 \%$ \\
\hline $\operatorname{Rev}$ & 16,053 & 49,024 & 3,287 & 5,414 & 8,179 \\
\hline Audit $\%$ & 34.0 & 14.9 & 23.9 & 32.2 & 42.7 \\
\hline$M A S \%$ & 66.0 & 14.9 & 57.3 & 67.8 & 76.1 \\
\hline $\operatorname{Tax} \%$ & 27.5 & 17.6 & 14.3 & 22.9 & 38.3 \\
\hline Par & 18 & 23 & 7 & 11 & 19 \\
\hline$C P A$ & 68 & 256 & 5 & 11 & 24 \\
\hline Emp & 68 & 126 & 18 & 37 & 60 \\
\hline Large & 0.09 & 0.28 & 0 & 0 & 0 \\
\hline \multicolumn{6}{|c|}{ Panel B: Large $(\mathrm{n}=111)$} \\
\hline $\operatorname{Rev}$ & 121,345 & 122,746 & 29,280 & 60,691 & 185,221 \\
\hline Audit\% & 51.6 & 13.8 & 41.0 & 49.5 & 61.0 \\
\hline$M A S \%$ & 48.4 & 13.8 & 39.0 & 50.5 & 59.0 \\
\hline Tax $\%$ & 14.4 & 6.4 & 11.1 & 14.5 & 17.9 \\
\hline Par & 71 & 45 & 41 & 55 & 100 \\
\hline$C P A$ & 620 & 641 & 132 & 335 & 943 \\
\hline Emp & 357 & 279 & 155 & 244 & 564 \\
\hline \multicolumn{6}{|c|}{ Panel C: Small $(\mathrm{n}=1,151)$} \\
\hline Rev & 5,899 & 4,569 & 3,053 & 4,930 & 7,168 \\
\hline Audit\% & 32.3 & 13.9 & 22.5 & 31.1 & 39.7 \\
\hline$M A S \%$ & 67.7 & 13.9 & 60.3 & 68.9 & 77.5 \\
\hline Tax $\%$ & 28.8 & 17.8 & 14.8 & 24.8 & 39.9 \\
\hline Par & 13 & 9 & 7 & 11 & 17 \\
\hline$C P A$ & 15 & 17 & 5 & 10 & 18 \\
\hline Emp & 40 & 34 & 17 & 35 & 51 \\
\hline
\end{tabular}

Notes: Rev: Total revenue; Audit\%: Ratio of audit revenue; Tax\%: Ratio of tax revenue; MAS\%: Ratio of management advisory services revenue; Par: Number of partners; CPA: Number of CPAs; Emp: Number of other employees; Large: Dummy variable that equals one if the firm is large, and 0 otherwise; Std: Standard deviation; Med: Median.

\section{Results of Regression Analysis}

Table 3 shows the results of the pooled OLS regression analysis by firm size from 2000 to 2014. Here, total revenue serves as the dependent variable. Partners, CPAs, and general employees exhibited significant positive regression coefficients for the full sample as well as for small accounting firms, which means that human resources contribute to the creation of revenue. For the full sample, a $1 \%$ increase in the number of partners increased total revenue by $0.45 \%$, while a $1 \%$ increase in the number of CPAs and general employees increased total revenue by $0.31 \%$ and $0.24 \%$, respectively. The contribution to total revenue of accounting firms was largest for partners, followed by CPAs and general employees, for the full sample and small firms. The regression coefficient of partners in large accounting firms, however, was not significant, although it was positive. Further, CPAs and general employees showed significant positive coefficients. The order of contribution in small accounting firms was the same as in the full sample; for large accounting firms, however, the largest contribution was from CPAs, followed by general employees and partners in decreasing order. 
Table 3. Results by firm size

\begin{tabular}{|c|c|c|c|}
\hline Variable & Full sample $(n=1,262)$ & Large $(n=111)$ & Small $(n=1,151)$ \\
\hline Intercept & $5.848\left(61.48^{* * *}\right)$ & $5.857\left(27.18^{* * *}\right)$ & $6.019\left(57.24^{* * *}\right)$ \\
\hline $\operatorname{lnPar}$ & $0.454\left(19.06^{* * *}\right)$ & $0.043(0.61)$ & $0.466\left(18.48^{* * *}\right)$ \\
\hline $\ln C P A$ & $0.312\left(25.90^{* * *}\right)$ & $0.673\left(16.94^{* * *}\right)$ & $0.286\left(22.56^{* * *}\right)$ \\
\hline $\ln E m p$ & $0.244\left(16.65^{* * *}\right)$ & $0.155\left(2.75^{* * *}\right)$ & $0.235\left(15.65^{* * *}\right)$ \\
\hline$M A S \%$ & $0.120(1.33)$ & $0.802\left(3.05^{* * *}\right)$ & $-0.035(-0.36)$ \\
\hline $\operatorname{Tax} \%$ & $0.147\left(1.90^{*}\right)$ & $0.504(0.95)$ & $0.172\left(2.21^{* *}\right)$ \\
\hline Large & $0.404\left(6.42^{* * *}\right)$ & & \\
\hline Year Fixed Effect & Yes & Yes & Yes \\
\hline F-value & 411.14 & 101.76 & 160.75 \\
\hline Adj. $R^{2}$ & 0.867 & 0.946 & 0.725 \\
\hline MRP (Par) & 408.8 & 72.1 & 215.7 \\
\hline $\operatorname{MRP}(\mathrm{CPA})$ & 73.3 & 131.6 & 112.7 \\
\hline MRP (Emp) & 57.8 & 52.5 & 34.7 \\
\hline
\end{tabular}

Notes: Tax\%: Ratio of tax revenue; $M A S \%$ : Ratio of management advisory services revenue; Par: Number of partners; CPA: Number of CPAs; Emp: Number of other employees; Large: Dummy variable that equals one if the firm is large, and 0 otherwise; MRP: Marginal revenue product of input (i), (i) = Par, CPA, Emp; The numbers in parentheses are t-values and ***,**, and * indicate significance at the $1 \%, 5 \%$, and $10 \%$ levels for the two-sided test.

The analysis of the MRP showed a similar result. In the full- and small-firm samples, partners' MRP was larger than that of CPAs, which was larger than that of general employees. Moreover, partners' MRP (CPAs' MRP) was larger in small (large) accounting firms, and partners' MRP in large accounting firms was smaller than that of CPAs. Partners' contribution and MRP in large accounting firms are analyzed in more detail in Table 4.

In large accounting firms, $M A S \%$, which represents the ratio of revenue from management advisory services relative to total revenue, was significantly positive, suggesting that the larger the ratio of management advisory services, the larger the total revenue of large accounting firms. On the contrary, in small accounting firms, Tax\%, which represents the ratio of tax revenue, was significantly positive, implying that the larger the ratio of tax revenue, the larger the total revenue of small accounting firms. Accounting firms of different sizes presumably have different service revenues, given their diverse human resource structures. For large accounting firms, IT services (e.g., the design and construction of business systems) and management advisory services (e.g., M\&As) significantly contributed to total revenue, while for small accounting firms, tax services (e.g., tax adjustments) were a significant factor. The dummy variable (Large) of large accounting firms showed a significantly positive value, which means that the total revenue of large firms is greater than that of small firms, even after considering the effect of the human resources input on total revenue.

Table 4. Results by period

\begin{tabular}{|c|c|c|c|c|}
\hline \multirow[b]{2}{*}{ Variable } & \multicolumn{2}{|c|}{ Large } & \multicolumn{2}{|c|}{ Small } \\
\hline & $\begin{array}{c}2000-2006 \\
(n=55)\end{array}$ & $\begin{array}{c}2007-2014 \\
(n=56)\end{array}$ & $\begin{array}{c}2000-2006 \\
(n=389)\end{array}$ & $\begin{array}{c}2007-2014 \\
(n=762)\end{array}$ \\
\hline Intercept & $5.802\left(23.32^{* * *}\right)$ & $5.529\left(28.50^{* * *}\right)$ & $6.16\left(27.27^{* * *}\right)$ & $5.748\left(58.54^{* * *}\right)$ \\
\hline $\operatorname{lnPar}$ & $-0.176\left(-1.76^{*}\right)$ & $0.269\left(3.80^{* * *}\right)$ & $0.547\left(10.39^{*}\right)$ & $0.427\left(16.52^{* * *}\right)$ \\
\hline $\ln C P A$ & $0.719\left(11.32^{* * *}\right)$ & $0.664\left(16.50^{* * *}\right)$ & $0.291\left(9.90^{* * *}\right)$ & $0.281\left(24.04^{* * *}\right)$ \\
\hline $\ln E m p$ & $0.344\left(4.85^{* * *}\right)$ & $-0.094(-1.67)$ & $0.211\left(7.87^{* * *}\right)$ & $0.243(14.44)$ \\
\hline$M A S \%$ & $0.042(0.13)$ & $2.014\left(7.26^{* * *}\right)$ & $-0.485(-2.48)$ & $0.436\left(4.36^{* * *}\right)$ \\
\hline $\operatorname{Tax} \%$ & $-0.292(-0.40)$ & $1.261\left(2.53^{* *}\right)$ & $0.044(0.25)$ & $0.198\left(2.72^{* *}\right)$ \\
\hline Year fixed effect & Yes & Yes & Yes & Yes \\
\hline F value & 80.40 & 240.92 & 57.29 & 241.02 \\
\hline Adj. $\mathrm{R}^{2}$ & 0.942 & 0.981 & 0.615 & 0.791 \\
\hline MRP (Par) & -281.0 & 478.3 & 217.8 & 209.8 \\
\hline MRP (CPA) & 128.5 & 135.9 & 88.5 & 124.0 \\
\hline MRP (Emp) & 80.6 & -40.1 & 25.3 & 39.2 \\
\hline
\end{tabular}

Notes: Tax\%: Ratio of tax revenue; MAS\%: Ratio of management advisory services revenue; Par: Number of partners; CPA: Number of CPAs; Emp: Number of other employees; Large: Dummy variable that equals one if the firm is large, and 0 otherwise; MRP: Marginal revenue product of input (i), (i) = Par, CPA, Emp; The numbers in parentheses are t-values and ${ }^{* * *},{ }^{* *}$, and $*$ indicate significance at the $1 \%, 5 \%$, and $10 \%$ levels for the two-sided test. 


\section{Additional Analysis}

One accounting policy that had the greatest effect on the accounting market from 2000 to 2014 was the introduction of IFRS, which was enacted as a single accounting standard that reflected the economic realities of ensuring higher transparency and comparability of accounting information against the backdrop of the internationalization of the capital market. The implementation of accounting standards that fit economic realities requires complex judgment and procedures, and both companies and auditors require more labor to draw up financial statements, according to IFRS, before and after auditing.

The introduction of IFRS also affected the demand for accounting by companies. Indeed, the full introduction of IFRS for listed companies in 2011 was not a simple change in accounting standards; it had a huge impact on the auditing market. Hence, the introduction of IFRS changed not only accounting standards, but also the demand for the auditors required to interpret and judge these standards. Wieczynska (2016) investigated the EU from 1998 to 2010 and found that companies adopting IFRS replaced auditors with global accounting firms. Hence, the introduction of IFRS is expected to lead to differences in the contribution of human resources, depending on firm size. Banker et al. (2005) explained that the productivity of large accounting firms alters according to environmental changes, such as improvements in service technologies. Additionally, Chang et al. (2009a, 2009b) analyzed the productivity of large accounting firms in the United States before and after the introduction of SOX, and confirmed that the increase in consulting revenue has enhanced productivity since the introduction.

Although Korea introduced IFRS in 2011, the practical impact on the accounting industry began in 2007, when the roadmap was announced, as the hiring and training necessary to review prior validity and apply IFRS to listed companies began then, in earnest. In fact, management advisory services for large accounting firms increased from 322 billion won in 2007 to 388 billion won in 2008 and 515 billion won in 2009 (see Panel A of Table 1). Thus, this study set 2007 as the reference point for the introduction of IFRS. ${ }^{7}$ The change in demand for labor in the auditing market is assumed to influence the productivity of all accounting firms, despite their different human resources structures.

Referring to Table 4, the results of the regression analysis on the difference in the contribution of human resources by firm size before and after 2007 are presented. This table highlights that partners' contribution in large accounting firms showed a significant positive correlation after the announcement of the IFRS roadmap in 2007. The increase in the market share for large accounting firms of listed companies, which are required to introduce IFRS, can be attributed to the role of partners whose major work is to manage clients. The contribution of general employees, however, decreased after 2007, probably because of the revision of the CPA law in 2003, which prohibited the same auditors from providing non-audit services such as consulting. IT experts and professionals with $\mathrm{PhD}$ degrees, who mainly provide management advisory and consulting services in large accounting firms, were classified as general employees. Further, as the consulting sector of KPMG headquarters was separated into an independent firm following the effect of SOX, the number of general employees in large accounting firms in Korea decreased after 2003 (as shown in Figure $3)$.

After 2007, the sign of partners' (general employees') MRP changed to positive (negative). Moreover, most listed companies are audited by large accounting firms. Thus, after 2007, the human resources' contribution of large accounting firms changed as partners' contribution and MRP were optimized to fit their role and a fair level of remuneration in line with environmental changes. On the contrary, the human resources' contribution of small accounting firms showed no significant change, even after the introduction of IFRS, perhaps because the effect on small accounting firms was relatively low following its introduction. ${ }^{8}$

$M A S \%$ and Tax\% exhibited significant positive correlations after 2007 in both large and small firms, which is interpreted as the gradual increase in the contribution of non-audit services to total revenue, regardless of firm size.

\footnotetext{
${ }^{7}$ Setting 2009—when prior notifications needed to be specified for the mandatory application of IFRS in 2011—as the reference point produces the same results.

${ }^{8}$ For reference, instead of classifying accounting firms into large and small, classifying them into those with and without an affiliation with the Big 4 produces the same regression results as previously described. However, since the number of observations of the Big4 accounting firms is small, the F-values indicating the suitability of the regression equation model are not significant.
} 
Only management advisory revenue in large accounting firms and tax revenue in small accounting firms had significant positive relationships with total revenue (please refer to Table 3). This is presumably because of the negative (although not significant) relationships between the tax revenue of large accounting firms and total revenue, and between the management advisory revenue of small accounting firms and total revenue before 2007, offset by the significant positive relationships after 2007.

The MRP of small accounting firms was largest for partners, followed by CPAs and general employees, both before and after 2007. In small firms after 2007, the MRP was 209 million won per partner, 124 million won per CPA, and 39 million won per general employee. In large accounting firms, the MRP after 2007 was 478 million won per partner and 136 million won per CPA. Additionally, partners' MRP showed a negative sign before 2007 and a positive sign thereafter, which is presumably because the somewhat fixed human resources structure was gradually optimized to the level of fair remuneration, by steadily adjusting to the changes in the environment (Green, Lensink, \& Murinde, 2001).

\section{CONCLUSION}

The accounting environment in Korea has undergone widespread changes since 2000. The revision of the AEASC and CPA law in 2003 strengthened the responsibilities of companies and auditors, as did the introduction of IFRS in 2011. The assets, sales, and number of firms subject to the AEASC, which are the major clients of accounting firms, have increased fourfold since 2000, with the revenue of the auditing market and number of CPAs rising by similar amounts. Based on the foregoing, this study systematically analyzed the relationship between total revenue and human resources - based on the labor classification of partners, CPAs, and general employees - according to environmental changes in the accounting market as well as firm size and period.

A concluding summary of the results of the presented empirical analysis is as follows. First, the larger the ratio of management advisory (tax) revenue, the larger the revenue of large (small) accounting firms. Second, when investigating the fairness of the wage gap in labor classification based on revenue creation competencies, we found that the MRP was the greatest for partners, followed by CPAs and general employees. Further, after 2007, the larger the ratio of management advisory services and tax revenue, the higher the total revenue in both large and small accounting firms, which is interpreted as the gradual increase in the revenue contribution from non-audit services, in line with the demand in the accounting market. Moreover, productivity by labor classification differs between the periods before and after 2007. After 2007, partners' contribution in large accounting firms significantly rose in the positive direction, and their marginal revenue was also the largest. Thus, partners of large accounting firms, whose major role is to manage clients, were presumed to have succeeded in securing the market share of listed companies, which were subject to the mandatory introduction of the IFRS roadmap in 2007.

In addition, partners' marginal revenue in large accounting firms was optimized to a fair remuneration level in response to changes in the environment. Meanwhile, general employees of large accounting firms significantly contributed to total revenue before 2007, but not thereafter, because of the contribution to total revenue from professional consulting labor (included in the general employees of accounting firms from 2000 to 2003, before the revision of the CPA law). In sum, depending on firm size, the productivity of each labor classification and the ratio of services to total revenue varied over time; however, the service ratio and productivity of human resources were optimized in response to changes in the environment.

The results of this empirical analysis imply that changes in the demand in the accounting market, as well as revisions to accounting regulations and standards, influence the productivity of accounting firms. Therefore, the presented results are expected to enhance the productivity and service levels of accounting firms by helping us better understand the characteristics of the accounting industry and provide appropriate policy support.

\section{AUTHOR BIOGRAPHY}

Sun-Min Kang is an associate professor of accounting in the College of Business Administration at Chung-Ang University. Her main research interests are accounting system and corporate governance. (First Author) E-mail: skang@cau.ac.kr 
In-Tae Hwang is a professor of accounting in the College of Business Administration at Chung-Ang University. His highly cited research focuses on financial reporting and valuation explaining the diversity in IFRS. (Co Author) E-mail: ithwang@cau.ac.kr

Kang-Sung Hur is a doctor of accounting in the College of Business Administration at Chung-Ang University. His research focuses on accounting accruals, the quality of earnings, non-audit services, and bank governance. (Corresponding Author) E-mail: hks522@cau.ac.kr

\section{REFERENCES}

Banker, R. D., Chang, H., \& Cunningham, R. (2003). The public accounting industry production function. Journal of Accounting and Economics 35(2), 255-281.

Banker, R. D., Chang, H., \& Natarajan R. (2005). Productivity change, technical progress and relative efficiency change in the public accounting industry. Management Science, 51(2), 291-304.

Banker, R. D., Chang, H., \& Natarajan, R. (2007). Estimating DEA technical and allocative inefficiency using aggregate cost or revenue data. Journal of Productivity Analysis, 27(2), 115-121.

Barros, C. P., Couto, E., \& Samagaio, A. (2014). Productivity analysis of UK auditing firms. Australian Accounting Review, 24(4), 381-393.

Chang, B.-G., Huang, T.-H., \& Kuo, C.-Y. (2015). A comparison of the technical efficiency of accounting firms among the US, China, and Taiwan under the framework of a stochastic metafrontier production function. Journal of Productivity Analysis, 44(3), 337-349.

Chang, H., Choy, H. L., Cooper, W. W., Parker, B. R., \& Ruefli, T. W. (2009a). Measuring productivity growth, technical progress, and efficiency changes of CPA firms prior to, and following the Sarbanes-Oxley Act. Socio-Economic Planning Sciences, 43(4), 221-228.

Chang, H., Choy, H. L., Cooper W. W., Parker, B. R., \& Ruefli, T. W. (2009b). Using Malmquist indexes to measure changes in the productivity and efficiency of US accounting firms before and after the Sarbanes-Oxley Act. Omega, 37(5), 951960.

Chiang, A. C. (1984). Fundamental methods of mathematical economics (3rd ed.). New York: McGraw Hill.

Choi, K. (1999). Production of audit Services and characteristics of audited company. Korea Business Review, $28(3), 609-635$. [printed in Korean]

Cobb, C. W., \& Douglas, P. H. (1928). A theory of production. U.S. Economic Review, 18(1), 139-165.

Green, C. J., Lensink, R., \& Murinde, V. (2001). Demand uncertainty and the capital-labour ratio in Poland. Emerging Markets Review, 2(2), 184-197.

Hwang, I. T., Kim, M. C., \& Jeon, Y.S. (2005). Performance and input of human resources of accounting firms. Working paper presented at Korean Accounting Association. Gwangju, December 19.

Hwang, I. T., Kang, S. M., \& Hur, K. S. (2015). Accounting firms human resources composition and management performance. Working paper presented at Korean Accounting Association, Dongguk University, December 19.

Lee, S.Y., \& Kim, H. J. (2001). Study on the relationship between the inputs and total revenue of an accounting firm. Korea Accounting Review, 26(4), 83-107 [printed in Korean].

Lee, S.Y. (2015). The impact of non-audit services on accounting firm productivity. International Journal of u-and e-Service, Science and Technology, 8(10), 41-52.

Money Today (2012). Accounting firm 'Big 4,' 75\% share of listed company... 'Big 4' accounting firm, average fee per listed company increased $4.6 \%$ year-on-year." September 11, 2012.

O’Keefe, T. B., Simunic, D. A., \& Stein M. T. (1994). The production of audit services: Evidence from a major public Accounting firm. Journal of Accounting Research, 32(2), 241-261.

Wieczynska, M. (2016). The 'Big' consequences of IFRS: How and when does the adoption of IFRS benefit global accounting firms?" Accounting Review, 91(4), 1257-1283. 